\title{
NOIVA NO AQUERONTE - COMPARAÇÕES ENTRE O DIREITO DE FAMÍLIA DA ANTIGUIDADE E CONTEMPORÂNEO
}

\author{
BRIDE IN ACHERON - COMPARISONS BETWEEN THE ANCIENT AND CONTEMPORARY FAMILY
}

LAW

\section{Caio Ferrari de Castro Melo* \\ Guilherme Grané Diniz**}

\begin{abstract}
Resumo:
Este artigo busca analisar a obra Antígone, de Sófocles, com a finalidade de nela buscar temas de Direito de Família que permitam melhor compreender, por meio de comparação e contraste com nosso Direito brasileiro contemporâneo, o Princípio da Afetividade. Assim, buscaremos explicitar os principais sentidos e significados conferidos por nosso ordenamento a este instituto, com a pretensão de concluir que o mencionado princípio pode ser visto como o parâmetro jurídico para formação do grupo familiar na contemporaneidade. Para que possamos realizar o proposto, passaremos por algumas leituras clássicas da peça e de temas dela, exporemos a fundamentação jurídico-doutrinária do Princípio da Afetividade em nosso Direito e concluiremos tratando do sentido geral que esta mudança aponta para o Direito de Família.

Palavras-chave: Direito de Família. Antígone. Princípio da Afetividade. História do Direito.
\end{abstract}

\begin{abstract}
:
This paper seeks to analyze the play Antigone, by Sophocles, in order to find Family Law subjects which may allow properly the construction of the principle of "affectivity", through comparisons and contrasts with the contemporary Brazilian Law. Thus, we shall try to make evident the main senses and meanings assigned by our legal system to this doctrine, with the intention of concluding that the mentioned principle can be seen as the juridical parameter for the formation of the family group in contemporary. In order to achieve this goal, some classical readings of the play and its subjects will be made, as well as the analysis of the legal and doctrinal foundations of the Principle of Affectivity in Brazilian Law. We shall conclude how this changes affected Family Law.
\end{abstract}

Keywords: Family Law. Antigone. Principle of Affectivity. History of Law.

* Caio Ferrari de Castro Mello é bacharel em Direito pela Universidade Presbiteriana Mackenzie e graduando em Ciências Sociais pela Universidade de São Paulo.

** Guilherme Grané Diniz é bacharel em Direito pela Universidade Presbiteriana Mackenzie e graduando em Filosofia pela Universidade de São Paulo e mestrando em Filosofia e Teoria Geral do Direito pela mesma Universidade. Para contatar os autores, por favor, utilize o e-mail: guilherme.diniz@usp.br. 
1. Introdução

Antígone é uma das obras de arte definitivamente mais lidas e comentadas pelos juristas. Como ressalta Katrin Rosenfield (2012, p. 42), o excesso de discussão sobre a questão do embate entre direito natural e positivo no âmbito da obra passou até mesmo a ser contraproducente, na medida em que obscurece outros pontos de interesse. $\mathrm{O}$ que nos propomos a analisar aqui não é este aspecto, mas sim alguns outros, especialmente, tomando por base considerações a respeito da relação entre Antígone e Hemon - este, perdidamente apaixonado, aquela, mantendo uma atitude fria e pouco receptiva, de fato sem em qualquer momento da peça falar com aquele que se propõe a casar com ela e, a partir disto, buscar levantar alguns outros temas do Direito de Família, inclusive abrangendo seus aspectos contemporâneos, principalmente o princípio da afetividade.

Escrita no século V a.C., a peça ainda é frequentemente representada, lida e, principalmente, debatida e interpretada, o que só demonstra sua força e expressividade. Guinsburg, por exemplo, atribui este poder à teatralidade da obra (VIEIRA, 2011, p. 14), ou seja, à sua grande "eficácia cênica", à tradução poderosa do texto para o palco. A grandeza da trilogia de Sófocles é tamanha que Aristóteles a tomou por padrão para expressar a estética do mundo grego dos séculos V e IV a.C. Partiremos, portanto, de algumas considerações de Aristóteles para entendermos melhor sobre a unidade de ação da tragédia grega.

Ora, até mesmo a definição que o Filósofo dá para a tragédia nos remete indiretamente às obras da trilogia tebana ("Édipo Rei", "Édipo em Colono" e "Antígone"): "Uma tragédia, então, é a imitação de uma ação que é séria e também, detentora de magnitude, completa em si mesma." (ARISTOTLE, 1941, p. 1.460). Esta definição encaixa-se perfeitamente nas três tragédias de Sófocles, principalmente na primeira e na última, e muito provavelmente foi pensada com elas em mente. Quanto ao comprimento das peças, elas devem ser curtas² (ARISTOTLE, 1941, p. 1.461), e de fato o são, já que precisam ater-se ao requisito da unidade de ação, entenda-se, devem conter em si seu começo, meio e fim, ${ }^{3}$ isto porque a arte é imitação, e a "beleza é uma questão de tamanho e ordem"4 (ARISTOTLE, 1941, p. 1.462). Assim como as coisas belas na natureza possuem uma ordem - nelas as partes têm uma sequência determinada e uma mesura que as permite

Todas as citações da Poética de Aristóteles são feitas com base nesta edição em tradução livre e contêm a referência à forma padronizada de citação de Aristóteles no rodapé (no caso, e.g., 1449b24). Gostaríamos de ter mais tempo para trabalhar com as concepções de Aristóteles sobre a tragédia, especialmente no que ela dialoga com as de outros autores a serem mobilizadas em tempo. No caso, apenas traremos, na medida da necessidade, de alguns elementos que forem importantes para nossas considerações.

$2 \quad 1451 \mathrm{a} 6$.

$31450 \mathrm{~b} 24$.

$4 \quad 1450 \mathrm{~b} 36$. 
serem compreendidas por homens cujos sentidos apenas abarcam coisas determinadas também deve ser com a arte. Devemos nos lembrar de que só a peça “Édipo Rei” é citada onze vezes no texto de Aristóteles em várias situações nas quais é usada como exemplo para as outras tragédias, logo, tratar aqui de todas as formas como a obra se apresenta no texto aristotélico é improdutivo. Apenas mostramos como os elementos que Aristóteles pensa como centrais ou constitutivos em sua definição de tragédia dão conta de explicar, ao menos em boa parte, as características principais das peças da trilogia tebana.

A história não é muito comprida, e nem poderia sê-la, uma vez que se restringe ao requisito de unidade de ação nos termos do que já foi dito, mas é de grande densidade não só artística como, inclusive, conceitual, o que ensejou uma série quase interminável de comentários e referências ao longo dos milênios. Até hoje se debate sobre o verdadeiro sentido das palavras de Sófocles. Esta exigência da unidade de ação é percebida em vários aspectos da obra, por exemplo, no fato de que boa parte dos acontecimentos relevantes à mesma não ocorre dentro da peça, somente sendo nela referida, assim como Aristóteles aponta acontecer na Odisseia de Homero (ARISTOTLE, 1941, p. 1.463). ${ }^{5}$ Isto é relevante para termos consciência de que muitos dos elementos que serão aqui explicados não são partes efetivas do trabalho de Sófocles, mas sim do imaginário popular da época. ${ }^{6}$

\section{Sobre a Obra}

Achamos por bem realizar aqui um sumário pormenorizado, mas certamente, não exaustivo de alguns pontos principais da peça, de modo a termos elementos da obra para análise. Apenas ressaltamos dentre algumas leituras os pontos que julgamos cruciais para a compreensão do trabalho que se desenvolve. Assim, pretendemos apresentar, de modo contextualizado com alguns comentários relevantes pontos centrais da peça, de modo que possamos depois melhor trabalhar com estes elementos ao longo do resto deste texto.

A peça inicia-se com uma invocação muito particular (VIEIRA, 2009, p. 25) por parte de Antígone a sua irmã Ismene, no sentido de alertá-la sobre novo decreto instaurado pelo general Creon, ao mesmo tempo tio e tio-avô das duas personagens. A nova Lei ordenava que somente um dos irmãos de Antígone e Ismene fosse enterrado (VIEIRA, 2009, p. 26), pois que tendo ambos lutado um contra o outro, sucumbiram, mas

1451a23-24.

6 Uma última nota antes de adentrar o texto. Optamos pelos nomes Antígone e Creon, assim como faz Trajano Vieira, diferentemente de algumas outras traduções, por estarem eles mais próximos dos termos gregos que lhes originam e dão significado (Antígone - anti/gonos, o contrário da geração; Creon - governante). 
um em serviço da pólis (Etéocles) e outro no afã de tomá-la (Polinices), este último não recebendo as honras funerárias.

Antígone pede, então, à sua irmã que a ajude a sepultar Etéocles, indo contra o que determinou o decreto impeditivo de Creon (VIEIRA, 2009, p. 27). A recusa de ajudar por parte de Ismene enfurece sua irmã (VIEIRA, 2009, p. 28), que decide dar cabo de concluir com suas próprias mãos o rito fúnebre, mesmo sabendo que isso vai levar à sua própria morte, que mais do que esperada, é desejada (VIEIRA, 2009, p. 29).

Logo em seguida, temos a primeira ode, que trata ambiguamente do Sol como um olho (VIEIRA, 2009, p. 31). Esta associação é recorrente no âmbito da trilogia, bem como a figura do olho toma nela um papel muito destacado. Devemos nos lembrar que os olhos são concebidos como os órgãos principais de intelecção; é por meio deles, em primeiro lugar, que tomamos conhecimento do mundo que nos cerca. Na peça "Édipo Rei”, o personagem principal, ao perceber, que dormira com a própria mãe e matara o próprio pai, fura seus olhos. Tal ato simboliza uma recusa de relacionar-se cognitivamente com o mundo; é o desejo de não saber o que se passa, já que foi o conhecimento e a busca por ele que o levaram a uma situação de miséria extrema (VIEIRA, 2011, p. 103). É por meio da ode ao Sol que ficamos sabendo do acontecimento da guerra dos sete contra Tebas (VIEIRA, 2009, p. 32), na qual os irmãos Etéocles e Polinices "auferem a moira comum de tânatos" (VIEIRA, 2009, p. 33). O Sol tem a dupla função aqui de ver e dar visão, ele é testemunha da guerra passada e condição para que se conheça dos acontecimentos que se passam, bem como um olho que vigia os acontecimentos e informa do mundo.

Após essa ode, Creon entra em cena pedindo para ser guiado pelo coro, exaltando as virtudes cívicas e condenando os que manifestam contra a urbe (VIEIRA, 2009, p. 35). Um guarda se aproxima de Creon e alerta, com muita cautela e hesitação, que pessoa desconhecida havia violado o decreto, sepultando Polinices e cumprindo os ritos fúnebres (VIEIRA, 2009, p. 38). Após graves ameaças de punir o guarda que descuidou de seus deveres, Creon direciona sua ira à verdadeira contraventora de suas leis, pega em flagrante delito repetindo o ato: sem resistir, sem negá-lo (VIEIRA, 2009, p. 47). Entre a ira de Creon e a captura de Antígone, ocorre a famosa "Ode ao Homem” (VIEIRA, 2009, p. 42-45). Nela encontramos uma das mais penetrantes descrições acerca do homem; o coro chama-o de assombroso (deinón).

Note-se que o termo em grego é ambíguo, “é um ser maravilhoso e estranho, não à vontade, ou em harmonia, com o mundo da natureza; um ser natural que destrói a natureza para fazer a si mesmo um lar, que depois modifica sua própria natureza para fazer ele mesmo cidades" (NUSSBAUM, 2001, p. 73), ${ }^{7}$ ao mesmo tempo que traz em si

Preferimos traduzir livremente os trechos citados da autora do que utilizar a tradução brasileira disponível. 
o sentido da grandeza e majestade, traz o assombro, a incompreensibilidade. É de notar como esta ode entretece uma gama de temas, especialmente ligados à dualidade entre técnica e natureza ou cultura e natureza. O ser humano é colocado como possuidor de tanto poder no sentido de mobilizar a técnica que é capaz de mudar não só a natureza em geral mas inclusive sua própria natureza. Assim, o homem estaria se separando do mundo das coisas naturais e criando a si próprio.

A questão que Nussbaum percebe na articulação que Sófocles faz destas questões é a da insuficiência do artifício perante o mundo ético. Se dependemos sempre de acontecimentos externos para sermos felizes e levarmos uma boa vida, só por meio de artifícios podemos tentar controlar este mundo (NUSSBAUM, 2001, p. 2). Contudo, em "Antígone" vemos justamente esta insuficiência; existem situações nas quais o conflito é inevitável, nas quais não importa como busquemos aplicar nossa razão, o caminho para a vida pacífica e louvável já está perdido (NUSSBAUM, 2001, p. 51). Esta ode é prenhe de sentidos, mas aqui se entreve claramente a crítica à razão que se pode atribuir a Sófocles, por exemplo, na figura de Édipo. A relação do autor com a razão e o papel desta na peça são temas a serem retomados em certa medida no futuro deste texto, mas é relevante saber como este atributo propriamente humano aqui tem o sentido de retirar o homem da ordem natural das coisas.

A tragédia se desenvolve e então é iniciada uma das maiores altercações verbais da história da literatura ocidental. Creon questiona Antígone se ela estava ciente do veto e qual a razão de ter praticado a violação de tentar praticar o ato fúnebre do irmão. A personagem responde se valendo de cinco argumentos (VIEIRA, 2009, p. 48); de início questiona o poder de Creon contra leis não escritas, perenes, ao que Creon responde que "Não sabes que o cabeça dura tomba/ precocemente e o aço temperado/ na chama, hiperrijo, é o que primeiro/ descasca e se estilhaça? Basta a brida”, acusando Antígone de intransigência para com o determinado em seu decreto. Este tema é retomado depois por Hemon, mas desta vez contra o próprio Creon.

O segundo argumento da personagem é que ela tem o suporte do povo e o medo que tem de Creon lhes trava a língua, ao que Creon replica: "nenhum outro tebano lhes vê desse ângulo". O próximo argumento de Antígone é que não há vergonha em honrar um consanguíneo. Já Creon responde que "ao vil não cabe o lote do homem íntegro", ao que Antígone interpõe que as distinções dentre amigos e inimigos não cabem no Hades, do que Creon discorda (VIEIRA, 2009, p. 53). O último argumento de Antígone é que foi feita para o amor e não para a intriga, então Creon perde a compostura e a manda "amar nos baixios", ou seja, no Hades. Este é um indicativo pertinente à interpretação que será defendida mais à frente.

Em momento seguinte, adentra Ismene no recinto, considerada inimiga por Creon e por Antígone, apesar de buscar o mesmo destino desta (VIEIRA, 2009, p. 54). 
Nesta parte Ismene põe a Creon uma questão que nos é por demais elucidativa para os fins deste trabalho: pergunta-lhe se assassinaria a noiva (VIEIRA, 2009, p. 56) de seu filho, já que reproduzir a conjuntura que une um par é algo muito raro. Creon considera Antígone vil e indigna de seu filho, dizendo que o Hades lhes rompeu o noivado (VIEIRA, 2009, p. 57). Saem ambas de cena para que após mais uma breve ode, relembrando a todos que sobre os personagens pesa a herança maldita do incesto de Édipo (VIEIRA, 2009, p. 5859), adentre Hêmon, o noivo de Antígone.

De início ele reconhece a autoridade do pai e de seus conselhos (VIEIRA, 2009 , p. 60), mas então começa a questionar a beleza (kalós $)^{8}$ da fala de seu pai. Repete o argumento de Antígone de que o povo estava contra o governante (VIEIRA, 2009, p. 63). Nesta mesma fala, Hemon usa uma metáfora muito relevante para as análises posteriores da obra, a da "árvore que verga quando estoura o vazante infernal" (VIEIRA, 2009, p. 64), relembrando a metáfora do aço temperado que por ser rígido quebra; utilizada anteriormente para falar de Antígone. A árvore que verga resiste à tempestade sem quebrar; é um dos motivos principais da peça, a impossibilidade de se ater a um valor único e imutável face às circunstâncias adversas que hão de surgir e fogem a nosso controle, apesar de todos os artifícios que este ser deinón pode criar (NUSSBAUM, 2001, p. 3-4).

Após uma forte disputa acerca da natureza e limites do poder do governante da pólis (VIEIRA, 2009, p. 65), Hemon ameaça seu suicídio, se mantida a condenação à sua amada (VIEIRA, 2009, p. 67). O coro então prossegue a exaltar Eros, divindade reconhecida como responsável pela paixão e a afirmar que não há quem escapa de seus poderes (VIEIRA, 2009, p. 69). Esta passagem é relevante, pois dá ensejo a uma questão muito bem pontuada por Martha Nussbaum, a de que apesar de ninguém se furtar ao seu "desvario" parece que é justamente isto que os dois personagens principais fazem (NUSSBAUM, 2001, p. 67). Nem Creon, nem Antígone mostram afeição por qualquer um, principalmente o primeiro. Já Antígone mostra um sentimento muito provavelmente incestuoso pelo irmão falecido, Polinices, como Trajano VIEIRA (2009, p. 20-21) aponta e como pretendemos estabelecer com elementos textuais mais a frente.

Mas é importante perceber que não ter Eros, mesmo que se mostre essencialmente na recusa, direta ou tácita, do afeto de seus pares, significa mais que apenas isto. No "Banquete" platônico, discorre-se acerca de Eros. Aristófanes conta uma lenda. Em um passado distante, havia um terceiro gênero de seres humanos, os quais eram andróginos. Eles não eram nem homens nem mulheres, mas continham em si ambos os sexos; eram pessoas duplas. Eram muito maiores, mais fortes e poderosos que um ser humano comum, já que cada um continha em si duas pessoas. Sua forma

Note que o termo grego também tem o significado de justiça ou bondade, o que remete à unidade dentre beleza e moralidade. 
era completamente arredondada, oito seus membros e dois seus rostos e seus genitais (PLATÃO, 1973, p. 28). Com o tempo estes humanos andróginos passaram a confiar tanto em seus poderes que desafiaram mesmo os deuses, que decidiram dividi-los para assim torná-los fracos, criando a partir de cada um deles um homem e uma mulher. Desde então, estes eternamente se buscam para poderem complementar-se. Quando enfim estas pessoas encontram-se, nunca mais tem o desejo de se separar, e querem de todo modo tentar unir seus corpos daquela forma pela qual eles estavam unidos antes (PLATÃO, 1973, p. 29). Eros é este desejo, esta força quase que natural, que impele as pessoas umas às outras como imãs; pedras amantes. A pessoa sem Eros não é só uma pessoa sem amor e sem desejo, é uma pessoa mutilada, frágil, é alguém que se encontra cindido em sua própria natureza e não possui apenas em si a capacidade de superar esta cisão (PLATÃO, 1973, p. 32). Aquele que não tem Eros está, por definição, sujeito à tragédia.

Enfim, adentramos a sequência final da peça. Antígone se despede da pólis, lamentando sua morte casta (VIEIRA, 2009, p. 70) depois de tanta obstinação e aparente aceitação de seu destino. Após momento de grande liricidade, onde a heroína invoca a proteção e o amor de seus familiares, aceita seu destino como fruto do dever e amaldiçoa Creon a sofrer "a mesma pena que hoje ele me imputa" (VIEIRA, 2009, p. 76), e é conduzida a seu sepulcro, onde há de expirar. O coro então compara seu destino ao de outros heróis trágicos (VIEIRA, 2009, p. 77-78). O tema que os une nesta ode é a escuridão, a impossibilidade da visão. É notável o contraste com uma das odes anteriores, onde se exaltava o Sol, o olho que via e permitia ver, órgão de intelecção, etc.

O próximo passo é a entrada de Tirésias, o adivinho cego que guiou Édipo em sua jornada à descoberta de si mesmo como assassino incestuoso, auxiliado por uma criança. Vem ele para dar conselho a Creon, para informar-lhe que os deuses não lhe respondem mais as preces (VIEIRA, 2009, p. 80) e é vão persistir no erro de manter Polinices insepulto. Creon o acusa de estar sendo subornado (VIEIRA, 2009, p. 81), o vate se indigna e vai-se com a profecia de que Hemon morrerá até o fim do dia (VIEIRA, 2009, p. 83). Após ouvir o coro, Creon finalmente flexibiliza sua posição e corre a salvar Antígone da morte (VIEIRA, 2009, p. 85).

Em sua ausência, chega um mensageiro para narrar o acontecido ao coro enquanto preparavam o corpo de Polinices para o rito fúnebre. Escutam então a voz do filho do rei vindo da tumba de Antígone. Ao chegar, o encontram-no abraçado ao seu ventre enquanto ela pende da forca. Hemon matou-se após atacar o pai, agora Antigone completará o esponsalício onde Hades mora (VIEIRA, 2009, p. 92). Eurídice, mulher do rei, ouve a notícia da morte do filho e segue sua moira (VIEIRA, 2009, p. 95). O lamento de Creon faz perceber sua culpa e o coro conclui: "ninguém se esquiva ao que o destino determina" (VIEIRA, 2009, p. 98), uma frase que talvez possa sintetizar o espírito de toda a trilogia tebana. 


\section{O Princípio da Afetividade}

A obra-prima de Sófocles, de fato, pode ser compreendida de diversas formas, oferece inúmeras possibilidades de interpretação que são pertinentes às discussões do direito, inclusive da matéria específica de que trataremos nesta seção, o Direito de Família. No entanto, em parte, como já foi dito por Kathrin Rosenfield (2012, p. 42), pela obsessão dos juristas em tratar apenas de um dos pontos que toca ao Direito, aquele da contraposição entre Direito Positivo e Direito Natural, e em parte também por não dispor de arcabouço teórico-metodológico para abordar esse ponto de encontro deinón que se dá na intersecção entre direito e arte, podemos dizer que a obra não tem sido explorada no patamar das suas possibilidades de contribuição para o Direito.

Sabendo da impossibilidade de tratar de todos os aspectos que não foram abordados ainda pela ciência jurídica, frente à finitude dos nossos espíritos, bem como dispensando a pretensão de se valer de uma análise normativa dogmaticamente superficial sobre a aplicabilidade ou não de determinado dispositivo de lei aos acontecimentos narrados, é que limitaremos a extensão da nossa pesquisa ao Princípio da Afetividade no âmbito do Direito de Família.

Esse princípio, relativamente novo, manifestou-se em nosso ordenamento jurídico com a Constituição Federal de 1988, somente podendo ser compreendido por meio da interpretação sistemática de uma série de dispositivos da mesma, do Código Civil de 2002 (Lei n. 10.406/2002), do Estatuto da Criança e do Adolescente (Lei n. 8.069/1990), bem como da jurisprudência e doutrina brasileiras.

A percepção do princípio da afetividade como dotado de valor jurídico representa uma mudança no significado da família enquanto instituto jurídico, uma expansão de limites até então pouco determinados, mas que representam sem dúvida melhor adaptação do Direito para lidar com uma organização social complexa e multicultural. O que antes era tratado como uma união indissolúvel, desigual, mantenedora do patriarcalismo (GONÇALVES, 2014, p. 32), que diferenciava qualitativamente os filhos entre legítimos e ilegítimos e regulava de forma rígida até mesmo a configuração em que deveriam ser constituídas as relações amorosas e de parentesco, foi radicalmente reformulado. Decerto que tais mudanças não ocorreram abruptamente. No momento em que a Constituição da República de 1988 introduziu novidades para o Direito de Família, as consequências atuais do valor jurídico da afetividade ainda não estavam plenamente desenvolvidas, sendo necessária uma longa reflexão doutrinária e a positivação de institutos que consolidariam o valor jurídico de tal princípio.

Assim, as mudanças inicialmente trazidas foram complementadas por emendas e pela legislação superveniente, nomeadamente, pelo Código Civil, de 2002, pela Emenda Constitucional n. 66, de 2010, e o Estatuto da Criança e do Adolescente. 
Dias (2007, p. 67) explicita com propriedade os fundamentos constitucionais dos quais extraímos o princípio, quais sejam, o art. 227, $\S 6^{\circ}$, o qual postula a igualdade dos filhos, sejam "legítimos", "ilegítimos" ou adotivos; o art. 226, § 4, que institui a possibilidade de uma família monoparental e, enfim, o art. 227, caput, o qual informa-nos da prioridade da convivência familiar enquanto direito das crianças e dos adolescentes, todos dispositivos da Constituição Federal de 1988.

Marcondes (2013, p. 223), por sua vez, indica ainda o art. 229 da Constituição, o qual institui o dever dos pais de "[...] assistir, criar e educar os filhos menores [...]" como expressões do valor jurídico do chamado melhor interesse da criança. Entendemos que o princípio da afetividade tem valor jurídico mediado, no caso apresentado pela autora, pelo melhor interesse da criança e do adolescente. O melhor interesse referido, por sua vez, está baseado no princípio da dignidade humana (previsto no art. $1^{\circ}$, III, da Constituição Federal) na medida em que ele permite o pleno desenvolvimento da personalidade.

A segunda parte do art. 229 determina que, em contrapartida, “[...] os filhos maiores têm o dever de ajudar e amparar os pais na velhice, carência ou enfermidade". Nesse artigo não nos parece que a lei se refere somente ao aspecto material ao dispor sobre os deveres dos filhos de ajudar e amparar os pais, mas também quanto ao aspecto imaterial, moral e afetivo.

Destes artigos é possível extrair que há nas relações familiares disciplinadas no ordenamento jurídico brasileiro uma proteção que está além das relações patrimoniais e formais, que abrange também o campo das relações morais entre familiares. Nesse sentido, é possível interpretar que os arts. 226, $\S 4^{\circ} ; 227$, caput e $227 \S 6^{\circ}$ delineiam um sistema que não parte de pressupostos biológicos, religiosos ou meramente formais. Como veremos, as relações jurídicas de família no direito moderno podem partir do pressuposto das relações de afetividade para instituir o liame entre membros familiares. Modificações desse tipo quanto à regulação do matrimônio, por exemplo, acredita-se, só foram possíveis com a diminuição da influência do poder eclesiástico e a crescente secularização que vem dando novos sentidos à existência, manifestações próprias da modernidade.

Essas inovações se basearam em uma concepção mais pluralista de que existem formas diferentes de viver a vida das quais se conhecia - ou até então eram ignoradas - e que são válidas como uma forma de integração da sociedade, dando-se cada vez menos valor ao que lhe é dispensável e elevando a patamar de princípio aquilo que é essencial à unidade familiar. De acordo com Venosa (apud MARCONDES, 2013, p. 117) entende-se que o eixo do Direito de Família deixou de ser o autoritarismo para assumir a forma do afeto, a relação de família passou a ser percebida como uma relação afetiva ao invés de uma relação de poder e dominação.

A crescente relevância do princípio da afetividade no Direito de Família moderno causou uma ruptura com a visão até então vigente que teve origem na tradição 
francesa do Direito da Família (GONÇALVES, 2014, p. 41). Estas correntes perceberam em algum momento que a definição legal do instituto "família" era insatisfatória, de modo que buscaram complementar doutrinariamente as disposições normativas. Para tanto, foi necessário, como de praxe no direito, definir a natureza jurídica do instituto. Considerando que o vínculo fundamental que inaugurava a família era o casamento, trouxeram a ideia do contrato para o Direito de Família.

Entendia-se que o vínculo fundamental do casamento era o acordo de vontade entre os nubentes, daí decorrendo sua natureza jurídica contratual (GONÇALVES, 2014, p. 41). Um bom exemplo disso é o não reconhecimento de filhos havidos fora do âmbito de vigência da relação contratual e famílias monoparentais, formadas por laços fáticos e não jurídicos, que vigia anteriormente às inovações da Constituição de 1988.

Também famílias cuja relação não se constituía pelo instrumento jurídico adequado não eram consideradas passíveis de tutela judiciária familiar especializada, sendo as questões que surgiam deste vínculo tratadas por juízos de outras competências, principalmente de empresas. As relações entre pessoas do mesmo sexo - formadas por partes "ilegítimas" para tomar parte no contrato de matrimônio - tinham sobre si imposta uma forma contratual societária, a qual não correspondia à realidade em um plano sociológico. Eram consideradas para fins patrimoniais como sociedades de fato e a dissolução do vínculo era realizada como se fosse a resolução de sociedade empresarial. Essa prática, que já foi predominante no Direito brasileiro, pode ser evidenciada em julgados como o seguinte:

DIREITO CIVIL E PROCESSUAL CIVIL. DISSOLUÇÃO DE SOCIEDADE DE FATO. HOMOSSEXUAIS. HOMOLOGAÇÃO DE ACORDO. COMPETÊNCIA. VARA CÍVEL. EXISTÊNCIA DE FILHO DE UMA DAS PARTES. GUARDA E RESPONSABILIDADE. IRRELEVÂNCIA.

1. A primeira condição que se impõe à existência da união estável é a dualidade de sexos. A união entre homossexuais juridicamente não existe nem pelo casamento, nem pela união estável, mas pode configurar sociedade de fato, cuja dissolução assume contornos econômicos, resultantes da divisão do patrimônio comum, com incidência do Direito das Obrigações.

2. A existência de filho de uma das integrantes da sociedade amigavelmente dissolvida, não desloca o eixo do problema para o âmbito do Direito de Família, uma vez que a guarda e responsabilidade pelo menor permanece com a mãe, constante do registro, anotando o termo de acordo apenas que, na sua falta, à outra caberá aquele munus, sem questionamento por parte dos familiares. 
3. Neste caso, porque não violados os dispositivos invocados - arts. $1^{\circ}$ e $9^{\circ}$ da Lei n. 9.278 de 1996, a homologação está afeta à vara cível e não à vara de família.

4. Recurso especial não conhecido.

(REsp. 502.995/RN, Rel. Ministro FERNANDO GONÇALVES, QUARTA TURMA, julgado em 26/4/2005, DJ 16/5/2005, p. 353).

A forma pela qual se constitui a família moderna evidencia, portanto, uma descontratualização do matrimônio, bem como a relativização de uma fundamentação meramente formal para o casamento. O que antes era percebido como uma simples relação de acordo entre vontades se torna, agora, uma interação mais complexa, que leva em conta aspectos menos objetivos, mas aguçados no sentido de dar o devido tratamento jurídico à multiplicidade de tipos de famílias.

O afeto, salvo exceções de grupos muito particulares, é uma característica das relações humanas que encontra no seio da doutrina contemporânea grande receptividade (Cf. MARCONDES, 2013, p. 116-120). Ele tem reconhecido valor jurídico e alcançou o papel de princípio específico do Direito de Família. Tartuce (2013) traz em bem curto, porém, muito elucidativo artigo científico a exposição de forma sistemática daquilo que considera serem as três principais consequências deste princípio na jurisprudência brasileira: I) o reconhecimento jurídico da união entre pessoas de mesmo sexo como entidade familiar; II) a admissão da reparação por danos em decorrência do abandono afetivo e; III) o reconhecimento da parentalidade socioafetiva como nova forma de parentesco.

A primeira consequência, o reconhecimento jurídico da união entre pessoas do mesmo sexo como entidade familiar, foi em grande parte fundamentada com apoio no princípio da afetividade, ou como o chama Diniz (2008, p. 19) - princípio da ratio do matrimônio e da união estável. Agora já se entende que aquilo que é essencial à união de um casal, seja ele proveniente de uma relação heterossexual ou não, é o afeto entre esses indivíduos. O princípio da afetividade permitiu a ampliação do que poderia ser considerado como entidade familiar, possibilitando o reconhecimento jurídico da união dentre pessoas do mesmo sexo como entidade familiar por meio da união estável. A título de ressalva, o plenário do STF levantou a questão acerca da forma sob a qual estas famílias se constituem, ${ }^{9}$ se como união estável ou uma modalidade não prevista no rol exemplificativo do art. 206 da Constituição Federal. Como aponta Maluf (2010, p. 14), podemos pensar um dos desdobramentos do princípio da afetividade como sendo o direito

Informativo STF, Brasília, 2 a 6 de maio de 2011 - n. 625 . 
à orientação sexual, que se extrai do art. $5^{\circ}$ incisos II, X, XLI da Constituição Federal, dentre outros dispositivos que corroboram esta leitura.

Conforme decisão do Supremo Tribunal Federal de 2011, publicada no Informativo n. 625, prestigiado o princípio da afetividade e assegurado o direito à liberdade sexual, resta inaceitável impedir a jurisdicização das relações afetivas dentre homossexuais, conforme podemos observar:

Em passo seguinte, assinalou que, no tocante ao tema do emprego da sexualidade humana, haveria liberdade do mais largo espectro ante silêncio intencional da Constituição. Apontou que essa total ausência de previsão normativoconstitucional referente à fruição da preferência sexual, em primeiro lugar, possibilitaria a incidência da regra de que "tudo aquilo que não estiver juridicamente proibido, ou obrigado, está juridicamente permitido". Em segundo lugar, o emprego da sexualidade humana diria respeito à intimidade e à vida privada, as quais seriam direito da personalidade e, por último, dever-se-ia considerar a âncora normativa do $\S$ $1^{\circ}$ do art. $5^{\circ}$ da CF. Destacou, outrossim, que essa liberdade para dispor da própria sexualidade inserir-se-ia no rol dos direitos fundamentais do indivíduo, sendo direta emanação do princípio da dignidade da pessoa humana e até mesmo cláusula pétrea. Frisou que esse direito de exploração dos potenciais da própria sexualidade seria exercitável tanto no plano da intimidade (absenteísmo sexual e onanismo) quanto da privacidade (intercurso sexual). Asseverou, de outro lado, que o século XXI já se marcaria pela preponderância da afetividade sobre a biologicidade. Ao levar em conta todos esses aspectos, indagou se a Constituição sonegaria aos parceiros homoafetivos, em estado de prolongada ou estabilizada união - realidade há muito constatada empiricamente no plano dos fatos -, o mesmo regime jurídico protetivo conferido aos casais heteroafetivos em idêntica situação.

A segunda consequência da reestruturação do ordenamento conforme o princípio da afetividade está relacionado ao valor jurídico do afeto como fundamento para reparação de danos. O Superior Tribunal de Justiça, que até 2006 não entendia que o abandono moral de um pai em face do filho pudesse ensejar indenização a este ${ }^{10}$ muda de posição alguns anos depois, admitindo reparação civil pelo abandono afetivo. ${ }^{11}$ Nesta decisão, a Ministra Nancy Andrighi ressalta que é obrigação jurídica dos pais dar auxílio

10 STJ, REsp. 757.411/MG, Rel. Min. Fernando Gonçalves, Quarta Turma, julgado em 29/11/2005, DJ 27/03/2006, p. 299.

11 STJ, REsp. 1.159.242/SP, Rel. Min. Nancy Andrighi, Terceira Turma, julgado em 24/04/2012, DJe 10/05/2012. 
psicológico aos filhos, configurando em dano moral o não cumprimento desse dever. Os argumentos inovadores da referida Ministra em ementa são muito claros nesse sentido: ${ }^{12}$

2. O cuidado como valor jurídico objetivo está incorporado no ordenamento jurídico brasileiro não com essa expressão, mas com locuções e termos que manifestam suas diversas desinências, como se observa do art. 227 da $\mathrm{CF} / 88$.

3. Comprovar que a imposição legal de cuidar da prole foi descumprida implica em se reconhecer a ocorrência de ilicitude civil, sob a forma de omissão. Isso porque o non facere, que atinge um bem juridicamente tutelado, leia-se, o necessário dever de criação, educação e companhia de cuidado - importa em vulneração da imposição legal, exsurgindo, dai, a possibilidade de se pleitear compensação por danos morais por abandono psicológico.

4. Apesar das inúmeras hipóteses que minimizam a possibilidade de pleno cuidado de um dos genitores em relação à sua prole, existe um núcleo mínimo de cuidados parentais que, para além do mero cumprimento da lei, garantam aos filhos, ao menos quanto à afetividade, condições para uma adequada formação psicológica e inserção social. (STJ, REsp 1.159.242/SP, Rel. Min. Nancy Andrighi, Terceira Turma, julgado em 24/4/2012, DJe 10/5/2012, grifo nosso).

É preciso notar que o que se afirma aqui não é o dever de amar, proposição que soa absurda e é, no limite, obrigação impossível, já que não compete a nós (menos ainda ao Estado) controlar nossas afeições. Isso se extrai da própria etimologia da palavra, que remete ao latim affectus: aquilo que nos afeta, aquilo em relação ao qual somos passivos. Parece-nos ainda não ser tarde para dizer o que entendemos por afeto e afetividade enquanto princípio jurídico. O significado particular que reside no significante "afetividade", nas circunstâncias em que estamos tratando-o, é o de cuidado, zelo ou responsabilidade em suprir as condições mínimas de auxílio psicológico e tratamento que podem ser objetivamente analisadas e são esperadas da relação em foco. É importante destacar que afeto não se confunde com amor e que, por causa disso, abordagens que buscam entender o sentido jurídico de afeto a partir da noção de sentimento como a de Marcondes (2013, p. 117) podem dificultar o entendimento do sentido da afetividade para o direito. O que se tutela é o dever de cuidar, de dar o amparo esperado de um pai a um filho. Trata-se de um "direito ao pai". Não se trata de uma análise psicológica dos sentimentos dos indivíduos, mas somente o que é dedutível de seu comportamento

12 STJ, REsp. 1.159.242/SP, Rel. Min. Nancy Andrighi, Terceira Turma, julgado em 24/04/2012, DJe 10/05/2012. 
objetivamente demonstrado. Se a finalidade fosse de regular sentimentos, poderíamos falar em injusta intervenção estatal e arbitrariedade desmedida, visto que o direito não comporta de instrumentos - também não os deve ter - para julgar a qualquer modo as emoções que um ser humano tem por outro.

Não cabe, por causa disso, a nomenclatura imprecisa que parte da doutrina (e.g. SOUZA, 2013) tem adotado para o embasamento do princípio da afetividade: a "teoria do desamor". Sem necessidade, no Direito esse tipo de categorização colabora mais ainda para a confusão do que se entende por afeto no âmbito do Direito das Famílias e acaba abrindo possibilidades para equívocos, fortalecendo o entendimento errôneo de que o Direito atuaria como regulador de sentimentos e não de condutas. Pelo que pode ser extraído de alguma literatura sobre o tema (DALL'OGLIO JUNIOR, 2013), a teoria do desamor consistiria em base para a responsabilidade civil no âmbito familiar, correspondendo à "ação ou omissão voluntária" capaz de causar danos morais, da qual trata o art. 186 do Código Civil. O problemático, porém, é justamente estabelecer esta relação, como afirmar que a falta de amor é ato ilícito. Ora, se o amor é afeto ou paixão, incorremos nos problemas acima destacados, está ele fora de nosso controle, obrigar a amar é constituir em obrigação impossível de ser cumprida voluntariamente e, portanto, é obvio que tal teoria não pode ser aceita nestes termos. É como preleciona Hironaka (2005, p. 3):

[...] Ninguém pode ser obrigado a amar, é certo. Mas é certo também que ninguém pode restar sujeito ao capricho da ausência afetiva, especialmente naquilo que afeto represente de mais essencial daquele a quem se o sonega. [...].

A responsabilidade nestes casos pode decorrer do descumprimento de deveres objetivos de cuidado e assistência, não pela ausência de sentimento.

$\mathrm{O}$ último efeito concreto da atribuição de valor jurídico à afetividade no Direito brasileiro que trazemos para a discussão é o do reconhecimento da parentalidade socioafetiva. O tema já é enfrentado, desde 1979, por João Baptista Villela em artigo que trata da "desbiologização da paternidade" e vem ganhando relevância não só na jurisprudência, mas também na doutrina, como é possível perceber a partir de decisões que versam do reconhecimento da multiparentalidade. ${ }^{13}$ Nessas decisões é possível perceber onde existem relações de parentesco reconhecidas pelo direito que são provenientes de relação socioafetiva, além da fundamentada pela biologia, inclusive a despeito desta, como prova o ponto 4 da ementa do REsp. 1244957/SC:

13 TJSP, Apelação n. 0006422-26.2011.8.26.0286, $1^{\circ}$ Câmara de Direito Privado, Itu, Relator: Des. Alcides Leopoldo e Silva Junior, julgado em 14 de agosto de 2012. 
4. Mesmo na ausência de ascendência genética, o registro da recorrida como filha, realizado de forma consciente, consolidou a filiação socioafetiva - relação de fato que deve ser reconhecida e amparada juridicamente. Isso porque a parentalidade que nasce de uma decisão espontânea, deve ter guarida no Direito de Família.

O que se extrai dos três efeitos aqui apontados é como o princípio da afetividade põe para o direito um novo desafio, o de ver os indivíduos além da sua juridicidade, não apenas como sujeitos de direitos e obrigações, mas seres em toda a sua dimensão ontológica (PEREIRA, 2011, p. 59). Essa nova visão que a introdução do princípio da afetividade no ordenamento jurídico trouxe é de que existem pessoas por trás dos sujeitos jurídicos, que são mais do que titulares de bens. A ciência jurídica até então podia enxergar o homem apenas pelo recorte bastante específico de sujeito de direito; a partir da introdução do princípio da afetividade, esse paradigma se tornou deficiente. Note-se, se o comando legal se refere primária e principalmente ao Direito de Família, a nova orientação da teoria é uma questão para todo o Direito. O tomar de raízes deste princípio se fará concreto na medida em que ensejar a reformulação da ciência jurídica em sua célula básica.

Percebemos, assim, por meio de seus efeitos, a relevância do princípio da afetividade. Como ressalta Dias (2007, p. 68), "o afeto não é fruto da biologia". Aqui talvez tenhamos um ponto de inflexão na obra de arte que propusemos estudar. O Direito hoje trata da família como algo cujo principal fundamento é o afeto; já em Antígone, ocorre algo diferente, até mesmo porque, como já ressaltamos, ocorre a ausência de eros tanto para a heroína quanto para Creon. Um importante guia para podermos compreender o que Sófocles aceitava ser a base da família é Fustel de Coulanges.

Em sua obra paradigmática "A Cidade Antiga" o autor escreve: "A origem da família não está na geração, no afeto natural, nem no nascimento, mas na religião doméstica que unia intrinsecamente todos os seus componentes. A religião fazia com que a família formasse um corpo nesta e na outra vida" (COULANGES, 2000, p. 36-37). Percebe-se então a relevância de Antígone para compreendermos o direito de família e a família mesma.

A peça é senão um olhar artístico privilegiado sobre aquele momento de articulação da concepção ritualística de família Os laços que unem Antígone a Polinices não são apenas de ordem biológica ou afetiva. Na realidade, estes pouco importam; o que propriamente os constitui como membros de uma família é o dever religioso que ela tem de sepultá-lo. Negá-lo é negar o parentesco, o que Ismene faz (VIEIRA, 2009, p. 45). O casamento com Hemon não significa para ela qualquer união espiritual ou envolvimento sentimental, mas sim o dever religioso de adotar a "religião doméstica" dele e de Creon, unidos por este mesmo laço. Compreender as diferenças entre estas duas concepções de 
família, que se poderia dizer estarem nas extremidades de um desenvolvimento cultural milenar, é uma tarefa por demais enriquecedora e relevante, nos abrindo a possibilidade de compreender o princípio da afetividade em suas sutilezas e contrastes.

\section{A Família Grega em Antígone}

Há quem diga que o personagem de Antígone desempenha na última parte da trilogia tebana um feminismo embrionário (BUTLER, 2000, p. 1) e um papel moralmente superior (NUSSBAUM, 2001, p. 52); de certo modo, a leitura de Martha Nussbaum não se desprende disso. Não obstante os méritos dessa leitura, principalmente a interpretação acertada das teses paradigmáticas de Hegel sobre o tema, se verificarmos aquilo que se nos afigura como sendo a natureza da família no mundo grego, é possível perceber que, apesar de o caráter contestador das reivindicações de Antígone, esta representa um posicionamento reacionário calcado no fundamentalismo religioso que reafirma uma tradição que Fustel de Coulanges caracteriza como a mais antiga (COULANGES, 2000, p. 18).

Expliquemo-nos. A posição de Antígone em relação ao contexto da sociedade tebana consiste na defesa de valores que hoje corresponderiam ao que popularmente se chama reacionário, ou seja, a defesa da tradição pautada nos valores religiosos de uma sociedade que já à época poderiam ser chamados retrógrados: defendia a supremacia do divino sobre o humano. Essa perspectiva entende que o homem é incapaz de alterar as leis dadas a ele por Zeus, e, deste modo, não pode estabelecer por si os critérios para a formação da família. O que Antígone busca fazer é justamente "girar para trás a roda da história" (MARX; ENGELS, 2011, p. 68), enquanto que Creon representa um posicionamento para a época vanguardista. Hodiernamente, a ideia defendida por Antígone equivaleria a um posicionamento por meio do qual se defende a manutenção do padrão moral-religioso no que tange à constituição dos vínculos familiares e o próprio campo de possibilidades para tal, posição à qual se atribui o caráter exatamente de ser politicamente reacionário.

Existe uma leitura corrente da obra por meio da qual se pensa Antígone como moralmente superior a Creon. A respeito disto, faz bastante sentido a análise de Hegel, a qual afirma que o conteúdo ético das posições de ambos possui uma unidade e são necessários um em relação ao outro (HEGEL, 2004, p. 307). O que muitos não percebem ou insistem em ignorar nessa grande obra da literatura é que tanto Antígone como Creon são inflexíveis em suas posições e simplificam grosseiramente a questão moral com a qual lidam. Aquela talvez ainda mais que este por ter morrido pela sua ideia, enquanto que Creon renuncia sua posição extremada, proporcionando o enterro de Polinices (VIEIRA, 2009, p. 86). 
Neste sentido, é paradigmática, até pela força de seus argumentos, a leitura de Martha Nussbaum. Ela nos fornece três argumentos pelos quais afirma ser a posição de Antígone moralmente superior a Creon; a saber: que nos termos da peça, a escolha de Antígone é preferível; que a busca de Antígone pela virtude não envolve violência ou submissão de outras pessoas e, enfim, que esta personagem reconhece a contingência dentro de sua posição moral, ou seja, uma situação na qual o seu exercício requer o cancelamento das próprias condições para esse exercício, entenda-se, o sacrifício da sua própria vida (NUSSBAUM, 2001, p. 66-67). Não concordamos com esta tese. Observaremos os argumentos com minúcia um a um e tentaremos explicar em linhas gerais as objeções que percebemos serem formuláveis a cada um.

a) Primeiro argumento

Os três argumentos convergem para afirmar que Antígone é moralmente superior a Creon (NUSSBAUM, 2001, p. 66). Apenas para referência, cumpre dizer que textualmente esta conclusão está colocada no parágrafo logo antes do primeiro argumento.

Quanto ao primeiro argumento, ele toma por base a afirmação de que a escolha de Antígone é moralmente preferível nos termos da peça. Por mais que isto possa ser verdade, temos que considerar que tal afirmação é permeada por um parâmetro valorativo que nos permite comparar a eticidade dessas condutas. Mesmo que Sófocles veja Antígone como moralmente superior, isto não significa que nós também devamos vê-la desse modo, pois nosso ethos é outro. Nos furtaremos aqui à discussão não tão recente acerca da interpretação da obra de arte e de se ela deve ou não restringir-se à intenção do autor, mas a verdade é que parece que ao buscarmos o sentido de um trabalho artístico, devemos não tentar perscrutar a mente daquele que a escreve, mas sim nos limitar aos elementos nele contidos. Se o autor buscou dar a obra certo sentido, mas nela não encontramos elementos para tanto, ela não possui tal sentido; o oposto também é verdadeiro (Oscar Wilde defende uma posição semelhante a este respeito, $c f$. "The Critic as Artist”). Nisto, certamente tem lugar o modo como a cultura de uma época influência no modo como a obra era lida. Mesmo que a obra seja, em termos, objetiva, no sentido de que é a mesma para todos que a leem, a interpretação é subjetiva, pois os elementos que se ressaltam e as relações que os dão significado variam com a cultura.

A noção de ethos surge pela primeira vez na Ilíada, de Homero, onde ao fim do canto VI ele fala sobre a ida de Páris ao campo de batalha, comparando-o com um cavalo que, ao quebrar suas correntes, corre até encontrar ethea (plural de ethos); as habitações onde vivem os outros animais, onde se encontram os outros cavalos e éguas, onde tem riachos de água fresca, etc. (CAMPOS, 2003, p. 262). Neste sentido, podemos entender o termo como um habitat, um lugar capaz de dar a alguém identidade e prazer 
(KOIDE, 2012, p. 141). Avaliar Antígone com vistas à intenção do autor é fazer tabula rasa da história e das diferenças éticas que separam nosso mundo do seu. Por este motivo, afirmar que no mundo da peça a escolha de Antígone é mais valiosa que a de Creon, por mais que possa ser verdade, não é de todo relevante para dizer que, no nosso mundo, hoje, isto também seja válido. Expliquemos.

De acordo com a autora, a superioridade moral de Antígone adviria do fato que romper com o valor religioso seria menos radical que romper com o valor cívico. Por mais razoável que tal afirmação seja para o mundo grego, não o é para nós, se aceita com muito mais facilidade a quebra dos deveres religiosos que a dos deveres cívicos em geral, salvo exceções, é claro. Poder-se-ia objetar que apesar de geralmente aceitarmos o dever cívico impor-se sobre o dever religioso, o dever de enterro aos mortos ainda assim é mais relevante que os deveres cívicos em geral. Isso, contudo, não é precisamente verdade. Apesar de, de fato, podermos afirmar que romper com o dever de enterrar aos mortos seja uma violação maior que a da maioria ou parte considerável dos deveres cívicos, isto não ocorre porque o enterro seja um dever de ordem religiosa, mas sim outro dever cívico e humanístico, termos cuja abrangência em parte se confunde. Entende-se, portanto, que mesmo neste caso o valor religioso não é capaz de sobrepor-se ao dever cívico, o dever de enterrar os mortos é apenas mais uma modalidade daquele. O que mostramos é que em nosso ethos os deveres que Nussbaum chama cívicos sobrepõem-se de modo geral aos religiosos, e é mais valoroso à pessoa que defende aqueles do que quem defende estes.

Além disto, é equivocado afirmar, como faz a autora, que a crítica de Sófocles não abrange a ideia de Antígone de que os valores não são relativos à utilidade. A crença dela de que existem valores absolutos é inseparável de sua "single-mindedness"; criticar sua incapacidade de mudar sua posição é criticar a própria posição, uma vez que ela prega valores incapazes de ser alterados por sua natureza de decreto divino. Deste modo, mesmo a afirmação de que nos termos da peça Antígone é moralmente superior pode ser duvidada, na medida em que sua posição é condição necessária para a tragédia, tanto quanto a de Creon.

Neste sentido, se podemos concordar com Nussbaum que a obra é em essência a crítica das posições inflexíveis de seus personagens principais, não é verdade que a estrutura valorativa de Antígone é preferível à de Creon nos termos da peça, já que a posição dela consiste na afirmação da imutabilidade das leis tradicionais. Creon, pelo contrário, ao reconhecer a mutabilidade de seu horizonte ético pela maleabilidade das leis humanas, permite que dentro de sua própria concepção se mude de opinião, o que, em certo sentido, efetivamente faz. 
b) Segundo argumento

Uma análise mais atenta permite perceber que o que a autora valora negativamente na conduta de Creon é o fato de que ele exerce a regência. $\mathrm{O}$ argumento se articula no sentido exatamente de justificar este juízo. Fica implícito o juízo de valor que se faz, seja referente a Antígone ou Creon, por meio da qual se possa dizer que Antígone é moralmente superior.

Quanto ao argumento de que a posição de Antígone é preferível, pois não contém nenhuma submissão ou violência, nos parece novamente encontrá-lo equivocado. $\mathrm{O}$ que a heroína defende envolve, em primeiro lugar, a violência contra ela mesma. Antígone não duvida em momento algum de que sua morte seguirá como consequência necessária das opiniões que defende; aceitá-las é inegavelmente praticar um ato de violência contra si mesma. Mas ainda restaria afirmar que o que Antígone postula é mais aceitável por não abarcar a violência contra outras pessoas. Também é falso. Afinal, Antígone está inserida em uma rede de relações sociais de afeto que fazem com que a violência contra ela seja violência contra outros. Se podemos dizer que Antígone não é dotada de eros, o mesmo não é verdade sobre Hemon, o qual sofre com a iminente morte de sua noiva a ponto de suicidar-se, como vimos; fruto do que poderíamos chamar até mesmo de egoísmo da personagem-título, a violência contra si mesma é também violência contra Hemon. Calemos quanto ao sofrimento de Ismene pela perda da irmã para mostrar ainda que a posição de Antígone envolve a submissão não de uma ou outra pessoa, mas sim de toda uma polis enquanto agregação política, uma vez que suas ideias, ao envolverem o enterro de um traidor, honrando sua traição, subvertem os valores cívicos que dão coesão a este agregado de pessoas. Por isto também podemos dizer que apesar de Antígone de fato agir solitariamente, talvez até mesmo por isto, ela violenta o mundo e seus habitantes.

Simplesmente dizer que Creon exerce regência sobre as coisas e Antígone não as violenta não permite concluir a superioridade moral de Antígone; ou a regência tem de ser comparada a algum tipo de violência ou simplesmente devemos considerá-la uma ação imoral. Esta segunda formulação é preferível segundo o princípio de caridade ${ }^{14}$ por ser ela mais abrangente e menos questionável, mas, mesmo assim, a autora não traz elementos no texto que deem suporte a esta afirmação não trivial.

O que a autora parece estar fazendo, e ela insinua de fato isto, em mais de uma passagem de seu texto, é colocando a postura ativa de Creon (ela também o faz com outros personagens) como um desvalor. A ação é vista como algo que, por si, é indesejável

\footnotetext{
14 John Nolt (1984, p. 101) explica que o princípio de caridade consiste em que, ao acrescentar uma premissa implícita em um argumento, se escolha dentre as várias possíveis aquela que revele a versão mais forte do argumento.
} 
e imoral, enquanto que a passividade é por sua definição ou natureza, moralmente superior. Este pressuposto, pelo que consta, é parte de uma tradição feminista à qual a autora se filia. Contudo, em momento algum do texto, ela busca argumentar no sentido de explicar ou dar suporte a estas afirmações, que são bem pouco triviais.

\section{c) Terceiro argumento}

O último argumento de que trata a autora é textualmente confuso apesar de ser o mais relevante e logicamente o mais forte. De início, podemos dizer que o argumento encontra seus limites no fato de que, mesmo que a visão de Antígone a permita sacrificar seus fins, ainda assim não podemos dizer ser ela moralmente superior a Creon. Isto pois, mesmo se a posição deste não for tão complexa ou maleável, o personagem é capaz de abdicar dela, enquanto Antígone, mesmo com as vantagens de sua posição, segue até o fim sua intransigência, aceitando inclusive a morte na defesa de sua posição. Deste modo, ela é até mais violenta em sua negação da alteridade.

Contudo, dada a posição mesma, seu abandono da parte de Creon não é exatamente com ela incompatível; ao defender que os homens fazem suas leis e que um decreto seu tem o poder de alterar as tradições, o que se afirma é a valorização do humano, como que uma espécie de proto-humanismo. Nos interessa é que se a posição de Creon é que os homens mudam as leis, a própria mutabilidade da posição de Creon parece ser parte intrínseca desta. Surgindo a situação em que ela se faça necessária ou aconselhável, cabe apenas a ele, e não a qualquer Deus, tradição ou natureza, decidir por uma nova posição ética, a qual pode por sinal inclusive ser coincidente com a de Antígone. O homem pode muito bem decidir que sua lei deve ser idêntica à lei divina, acatá-la, buscar por meios científicos, místicos ou religiosos seus sentidos e inclusive declarar tal lei como imutável, ainda dentro da posição de que cabe ao homem fazer suas próprias leis.

Por isto é errado afirmar que Antígone é moralmente superior pelo mero fato de sua posição admitir a contingência e ela poder cancelar seu exercício sem ter de fato o alterado uma vez que Creon também pode fazê-lo, e o faz, mesmo que em uma leitura mais superficial tenhamos a impressão de que ele somente trocou sua opinião acerca dos valores. O que ocorre é de fato a mudança de conteúdo em sua posição, mas a posição mesma a admite como parte intrínseca de si, nos termos do que já se expôs. Existe ainda uma ligeira vantagem, neste aspecto, na posição do governante. A aceitação da contingência não o obriga a alterar estruturalmente sua posição, e a mudança que ocorre é muito menos radical. Tais considerações impedem que se diga que a posição de Antígone é mais complexa ou articulada que a de Creon; apesar de percebermos que o foco do argumento está em validar a afirmação que Antígone consegue agir heroicamente enquanto mantém sua vulnerabilidade, o que garante este caráter ambíguo quase queer 
(Nussbaum não é tão radical neste ponto quanto Butler) de Antígone. Sem a ideia atacada, o argumento como um todo não funciona, pois a superioridade de Antígone em relação a Creon resta perdida. O conflito que surge do confronto com o mundo na posição de Creon pode ser solucionada, mesmo que apenas o seja tarde demais; na de Antígone é onde tem espaço para o propriamente trágico, uma vez que o único modo que ela tem de lidar com as dissonâncias do mundo externo face às simplificações que ela faz para poder lidar com elas é a própria morte ou a extinção da opinião alheia. O modelo de Creon é aberto ao diálogo racional e pode resolver-se na alteração dos postulados concretos e individuais de sua moralidade sem que sua estrutura seja afetada.

Segundo Platão, o parentesco era considerado como uma comunidade dos mesmos deuses domésticos, a religião para a família grega é um elemento constitutivo e regulador das relações familiares. É por intermédio de Fustel de Coulanges que podemos perceber o quanto se dava importância à religião para os antigos, em especial no tocante ao culto dos mortos. Era, afinal, por meio dos ritos fúnebres que se estabelecia o grupo familiar do qual os indivíduos faziam parte (mediante um ancestral comum) e quem o fez no passado. Como se não fosse o bastante o apoio de documentos escritos por Plutarco que trazem a definição de irmão, a saber: "são dois homens que têm o dever de fazer os mesmos sacrifícios, de ter os mesmos deuses parentais e de partilhar o mesmo túmulo" (COULANGES, 2000, p. 52). Também podemos perceber isso no discurso em que Demóstenes procura provar o parentesco entre dois homens argumentando que só o eram aqueles que praticavam o mesmo culto, oferecendo as refeições fúnebres no mesmo túmulo. Em suma, a religião fazia “com que a família formasse um corpo nesta e na outra vida" (COULANGES, 2000, p. 37).

A concepção de moralidade na antiguidade não permitia fundar a família na afetividade como faz a modernidade, sendo esse o principal motivo pelo qual a família moderna e a antiga não se confundem. Enquanto a primeira estava calcada na religião, e em um sentido especial, na morte (daí o antí-gonos, "anti-nascimento", Antígone), a segunda está na afetividade; princípio positivo, gerador. Quanto à primeira, ensina Fustel de Coulanges:

O esteio da família não o encontramos tampouco no afeto natural. $\mathrm{O}$ direito grego como o direito romano não tinham em conta este sentimento. Este podia realmente existir no íntimo dos corações, mas para o direito não contava, nada era. O pai podia amar a filha, mas não the podia legar os seus bens. As leis de sucessão, isto é, aquelas leis de entre as demais que com mais exatidão traduzem as idéias formadas pelos homens acerca da família, essas, estão em flagrante contradição, tanto com a ordem de nascimento como com o afeto natural. (COULANGES, 2000, p. 36) 
Uma reflexão sobre os institutos da adoção, do casamento e da emancipação e seus fundamentos permitem que entendamos melhor como os gregos justificam a entrada, transferência ou saída de um indivíduo em uma família. O segundo instituto funciona como uma transferência, em se tratando da mulher, de família. A mulher que cresceu assistindo aos atos religiosos do pai passa, por meio do casamento, para a assistência dos de seu marido, negligenciando os deuses paternos e adotando novos é que ela passa a fazer parte da família do cônjuge, "a mulher nada mais tem de comum com a religião doméstica de seus pais: sacrifica no lar do marido" (COULANGES, 2000, p. 38).

Já, em relação à adoção, é possível perceber que o culto religioso também tem papel importantíssimo para que esta fosse realizada. A variar de tempos em tempos, Fustel de Coulanges nos indica os requisitos e o trâmite do processo que eram essenciais à adoção. Estipulava-se que somente o homem sem filhos do sexo masculino é que poderia realizar tal ato, adotando para si, um filho - também homem - que pudesse dar continuidade ao culto dos ancestrais daquela família. Como não era admissível que a mesma pessoa fizesse os rituais fúnebres em dois lares diferentes, o adotado deveria renunciar aos seus deuses da família anterior para que pudesse adentrar no culto familiar do adotando. A partir de então, o adotado se transformava num estranho à sua própria família de origem e esta não tinha, consequentemente, nem o direito de enterrá-lo caso viesse a falecer (COULANGES, 2000, p. 51). A adoção necessitava, de certa forma, do instituto da emancipação, dado que para entrar em uma nova família era preciso antes deixar a sua renunciando os deuses-lares naturais. Uma vez chancelada a saída da família por meio da renúncia a estes deuses, o indivíduo não haveria de ter nenhuma obrigação ou direito para com o grupo familiar anterior, nem estes com ele.

Nota-se como a família e o direito têm influências recíprocas um no outro. De fato, aquela dá os conteúdos e as normas para que o direito possa submetê-la à sua regulação. Do exposto, percebe-se que o direito tutelava a família sem levar em conta - em momento algum - a biologia ou o afeto. A família se baseava na religião, e é este princípio aquele pelo qual o ordenamento jurídico a normatizava. A lei conferia direitos relativos ao estado de família somente àqueles que cultuavam os mesmos antepassados e, mais do que isto, tinham um para com o outro deveres religiosos, no caso de Antígone, o mais sagrado dentre todos, o do rito fúnebre (COULANGES, 2000, p. 11).

$\mathrm{Na}$ peça, este enlaçamento ajuda a entender a recusa tácita de Antígone quanto ao casamento com Hemon. Como já foi dito, em momento algum a personagem se dirige a seu noivo ou demonstra qualquer tipo de afeição para com ele. Isto pode ser lido como uma recusa da parte de Antígone de abandonar os deuses-lares, o culto religioso que a une à sua família (COULANGES, 2000, p. 38). Caso a personagem se casasse com Hemon, reza a tradição que deveria obrigatoriamente deixar de cultuar os seus ancestrais masculinos para adotar os de seu marido. Renunciar ao casamento é, dessa forma, nunca 
se separar da família do irmão. Esse modo de ver as coisas pode vir ainda a reforçar a leitura (a ser mais a frente melhor apresentada) que sustenta ter Antígone um sentimento incestuoso por Polinices. Também temos de pensar no forte apego da parte da heroína por seu pai Édipo. Na obra anterior da trilogia, Édipo em Colono, Antígone acompanha o pai no exílio e reiteradamente dá provas de seu amor e afeição por ele (VIEIRA, 2005, p. 38), que é recíproco (VIEIRA, 2005, p. 90).

Além disso, ao fim da obra, Édipo toma um caráter heroico e torna-se protetor místico de Atenas (VIEIRA, 2005, p. 110), seus filhos homens estão mortos, somente restam ela e a irmã para prestar o culto devido ao pai e seus ancestrais. Além disso, somente ela restou na família para defender os direitos fúnebres de seu irmão, já que Ismene recusou a incumbência. Resumindo, podemos dizer que Antígone tem fortes interesses de ordem religiosa para não largar sua família. O que se extrai de muito interessante disto, e que reafirmaremos mais à frente, é que para a heroína a família se constitui por um laço com os mortos, e não com os vivos. Podemos acreditar que esta seja uma característica necessária deste tipo particular de família que vincula os membros pela religião, traduzindo-se em ritos fúnebres e responsabilidades para com os mortos.

Algumas leituras sustentam que Antígone não possui eros, sobre o que já falamos. Do contrário, outros autores (COULANGES, 2000, p. 38), aos quais nos subscrevemos, afirmam ter este tipo de sentimento para com o irmão falecido. Em um primeiro momento, ressaltamos a leitura de Hegel sobre este ponto muito específico. Para o filósofo, a questão não é tanto sobre o desejo sexual, mas sim as características intrínsecas da relação entre irmãos fazem com que o dever religioso seja para com ele muito superior ao que é de se esperar (HEGEL, 2004, p. 316). Contudo, é de se notar que o autor enxerga Antígone mais como um momento necessário na história do Espírito do que como uma obra dramática, de modo que prescinde de alguns elementos textuais.

Para afirmar que Antígone tinha este sentimento para com Polinices é imprescindível que apontemos os elementos textuais nos quais tal leitura se baseia. $\mathrm{O}$ primeiro a ser apontado é a passagem: "Hades, leito pan-nupcial, conduz-me viva às fímbrias do Aqueronte, sem núpcias, sem hino: Noiva no Aqueronte." (VIEIRA, 2009. p. 70-71). Ora, como Trajano Vieira (2009, p. 21) indica, o leito pan-nupcial deve ser entendido como o leito de todas as núpcias, ou então, o leito de todo tipo de núpcias. Esta leitura corrobora o que se depreende da passagem onde Antígone afirma ser "grata se morrer amando quem me amou, concluindo ao lado dele o rito" (VIEIRA, 2009, p. 28-29). A sequência do que nos é dito, dá uma pista de que modo devemos compreender a ideia de rito. Primeiro ela declara ao irmão seu amor e afirma que será grata se morrer, só então deseja completar com ele o rito. É muito sugestivo o fato de que o rito segue-se à morte, e não o contrário. Disto cremos poder extrair que o sentido atribuído ao rito nesta passagem não é o de rito fúnebre, mas sim o de defloramento. Esta leitura corrobora a ideia de que 
Antígone recusa Hemon; casando-se ou unindo-se de qualquer modo ao irmão, ela não será obrigada a abandonar seus deuses-lares e sua família em prol de uma nova. No mais, várias vezes ao longo da peça se reitera que sobre a família de Édipo recai sua maldição, a da confusão do parentesco; a maldição do incesto (VIEIRA, 2009, p. 49).

$\mathrm{O}$ interesse que temos no exposto acima é reforçar o argumento da unilateralidade e persistência de Antígone em suas ideias, buscando consequências que vão além da própria morte, ou seja, o incesto a consumar-se após esta. Quando pensamos então neste quadro geral dos elementos que compõem a noção de família na Grécia e o contrastamos com o de nossa época, podemos a partir deste movimento evidenciar características bastante interessantes. Algumas delas já foram apontadas, mas, com certeza, beneficiaremos da comparação para melhor enfocarmos, por um lado, as peculiaridades do Direito de Família em nossa época, e por outro, os sentidos próprios que a mobilização da temática familiar toma em Antígone.

\section{Thanatos e Eros}

A partir do momento em que identificamos em nosso ordenamento jurídico o Princípio da Afetividade, identificamos também que não existe, ao menos no âmbito do Direito de Família, mas quando considerado estruturalmente, em germe para todo o Direito, as condições para a tragédia. Isto serve, certamente, para evidenciar a distância que guardamos do Direito da Grécia Clássica. Consideremos algumas das coisas que já foram ditas.

No Direito Antigo, existia uma concepção de família a qual dependia rigidamente de laços formados pela religião. Ainda, não se tratava de qualquer religião, mas sim de um culto religioso aos mortos. Este sentido de família é aquele que existe como pano de fundo para o desenrolar da peça. O interdito de Creon apenas ganha seu pleno sentido quando se pensa na desonra enorme que era permanecer insepulto, o que significava não participar, após a vida, do culto familiar, recebendo as honras que lhe são devidas. As ações de Antígone, especialmente, derivam seu sentido desta noção de família antiga. Manter-se ligada incestuosamente a Polinices significaria manter-se no culto ao pai, Édipo, o qual podemos ver na segunda peça da trilogia ter um papel afetivo muito grande para a heroína. Casar-se com Hemon, por sua vez, significaria desligar-se de Édipo e Polinices e passar a cultuar antepassados estranhos a si, inclusive, em algum momento, o próprio Creon. Não é espantoso, portanto, que Antígone mostre a "ausência de Eros"; que ela sequer se dirija a Hemon ao longo da peça. Do ponto de vista jurídico, para a formação da família nada contava o afeto entre seus membros e onde este afeto era posto. Antígone, que já de princípio não se inseria perfeitamente bem dentro das redes comuns de relacionamento familiar (era filha e irmã de seu pai), utiliza-se deste "Eros" de uma 
forma disruptiva ou negativa. Ela ama aos mortos, quer fazer amor com os mortos após a morte ... e ainda por cima o morto em questão é seu irmão! A família grega não precisava do "eros", do afeto entre seus membros, para funcionar, ela formava-se pelo "thanatos". Por isto Antígone é uma personagem trágica, sua hybris encontra-se neste curto-circuito entre deuses. Antígone já é de princípio deslocada em sua rede de relações de parentesco. Ao inserir seu "eros" incestuoso sobre seu irmão morto, ela causa uma disrupção de alta intensidade nos pressupostos familiares da política.

O Princípio da Afetividade tem, para além de suas consequências e seus conteúdos acessórios, um sentido que lhe é fundamental. Do ponto de vista jurídico, a família forma-se pela afetividade entre seus membros. Não cabe mais hoje falar-se em requisitos para a formação da família. É irrelevante a diversidade dos sexos, a forma jurídica pela qual se estabeleceu o vínculo, consanguinidade. Uma vez comprovada a existência de um vínculo de afetividade entre pessoas, está caracterizada uma família, com todas as consequências jurídicas que isto pode ter. Tamanha amplitude no conceito garante com que quase nenhuma forma de relação humana fique excluída. Famílias monoparentais podem formar-se mesmo sem laços de sangue entre o pai ou mãe e as crianças; já é quase corriqueiro que crianças sejam registradas com mais de uma mãe ou um pai; já foi relatado o registro da primeira união estável entre três pessoas no país e para fins imobiliários, já se reconheceu como entidade familiar a coabitação entre irmãos. Isto é exemplificativo; dependendo de quanto demorar para que este artigo seja publicado esta lista estará mais ou menos obsoleta, mas é quase seguro que até lá algum novo tipo de relação já tenha sido reconhecida como família. Deste modo, ao menos no âmbito do Direito de Família, não cabe mais espaço para a tragédia. Quaisquer que sejam as formas que a família tome, as relações que a fundem, os liames que a unam, o Direito, do modo que hoje é formulado, está pronto para dar a elas guarida. É claro que isto não impede que ainda haja certo descompasso entre a regulamentação jurídica e a sociedade, mas talvez esta seja uma das poucas oportunidades que tenhamos de observar este descompasso ocorrer no sentido do Direito mostrar-se mais liberal e progressista que a sociedade em geral. Mesmo que obtendo o reconhecimento jurídico de sua situação como família, muitas destas entidades ainda podem encontrar no seio da sociedade, como um todo, forte resistência e preconceito de todas as formas; a tragédia não está de todo eliminada como possibilidade. Mas por outro lado é bem certo que o Direito revela, sob a adoção deste Princípio, ao menos o compromisso do Estado com, e não apenas, a inclusão de grupos tradicionalmente desprivilegiados, mas a tutela em geral da liberdade dos cidadãos no que lhes toca mais intimamente.

Conforme dizíamos, o fato de encontramos em nosso Direito contemporâneo o Princípio da Afetividade nos revela como, ao menos neste respeito, encontramo-nos a uma grande distância das sociedades da Antiguidade Clássica. Por um lado, afirmar este 
distanciamento é um truísmo. É claro que queremos fazê-lo apenas no que se refere ao Direito de Família. Quanto a isto, parece que boa parte do que tínhamos a dizer já ficou bastante evidente. Queremos encerrar nosso texto chamando a atenção do leitor para uma coisa. Evitamos fazer juízos de valor acerca desta distância. Muitos autores pensaram e pensam a Grécia Clássica como alguma espécie de "modelo" de civilização humana. Uma época de ouro da humanidade que faríamos bem em imitar. Este tipo de juízo não é recente e parece ser até que bem razoável; de fato a sociedade grega nos legou muitas coisas positivas, e a tradição nos conta dela que era algo de grande e glorioso, de modo que parece sim desejável que recuperemos ao menos algo daqueles tempos. Contudo, acreditamos que este trabalho mostra que, ao menos no Direito de Família, parece que o momento que vivemos hoje se coaduna melhor com nossas expectativas em relação ao que valorativamente desejamos de nossa existência em geral. Não queremos tirar nenhuma conclusão forte a respeito de nós e dos gregos, apenas dizemos que em nosso Direito de Família não existe tragédia, o que do ponto de vista do Direito, convenhamos, é mais adequado.

São Paulo, 22 de abril de 2016.

\section{Referências}

ARISTOTLE. Poetics. In: MCKEON, Richard (Ed.). The basic works of Aristotle. New York: Penguim Random House, 1941. p. 1.453-1.487.

BUNAZAR, Maurício. Pelas portas de Villela: um ensaio sobre a pluriparentalidade como realidade sociojurídica. Revista Direito UNIFACS - Debate Virtual, Salvador, n. 151, jan. 2013. Disponível em: <http://www.revistas.unifacs.br/index.php/redu/article/view/2458>. Acesso em: 5 nov. 2013.

BUTLER, Judith. Antigone's Claim. New York: Columbia University Press, 2000.

CAMPOS, Haroldo de. Ilíada de Homero. São Paulo: Benvirá, 2003. 2 v.

DALL'OGLIO JÚNIOR, Adilto Luiz. Teoria do desamor: a reparabilidade do abandono afetivo paterno-filial. Disponível em: <http://www.defensoriapublica.mt.gov.br/portal/uploads/artigos\%20 juridicos/Art_Teoria_do_desamor1.pdf>.Acesso em: 3. nov. 2013.

DIAS, Maria Berenice. Manual de direito das famílias. São Paulo: Revista dos Tribunais, 2007.

DINIZ, Guilherme Grané. A mais bela alma. Humanidades em Diálogo, São Paulo, v. 6, p. 91-100, dez. 2014.

DINIZ, Maria Helena. Curso de direito civil brasileiro: direito de família. São Paulo: Saraiva, 2008. v. 5.

FUSTEL DE COULANGES, Numa Denis. A cidade antiga. São Paulo: Martins Fontes; 2000. 
GONÇALVES, Carlos Roberto. Direito civil brasileiro: direito de família. São Paulo: Saraiva, 2014. v. 6.

HEGEL, Georg Wilhelm Friedrich. Fenomenologia do espírito. Petrópolis: Vozes, 2004.

HIRONAKA, Giselda Maria Fernandes Novaes. Aspectos jurídicos da relação paterno-filial. Carta Forense, São Paulo, ano 3, n. 22, p. 3, mar. 2005.

. Direito ao pai. Revista Jurídica Del Rey, Belo Horizonte, ano 3, n. 7, p. 20, dez. 1999.

. Direito ao pai: dano decorrente de abandono afetivo na relação paterno-filial. Boletim IBDFAM: Instituto Brasileiro de Direito de Família, Belo Horizonte, ano 5, n. 33, p. 3-4, jul./ago. 2005.

KOIDE, Kelly Ichitani. A militant rationality: epistemic values, scientific ethos, and methodological pluralism in epidemiology. Scientiae Studia, São Paulo, v. 10, Special Issue, p. 141-150, jan. 2012.

LOBATO, José Cristóbal Aguírre. O exercício abusivo do poder familiar e os limites da intervenção judicial na família. 2013. 194 f. Dissertação (Mestrado em Direito) - Faculdade de Direito, Universidade de São Paulo, 2013.

MALUF, Adriana Caldas do Rego Freitas Dabus. A Composição da família na pós-modernidade. Revista FMU Direito, São Paulo, v. 24, n. 34, p. 1-17, 2010.

MARCONDES, Laura de Toledo Ponzoni. Dano moral nas relações familiares. 2013. 311 f. Tese (Doutorado em Direito) - Faculdade de Direito, Universidade de São Paulo, São Paulo, 2013.

MARX, Karl; ENGELS, Friedrich. Manifesto comunista. São Paulo: Hedra, 2011.

NIETZSCHE, Friedrich Wilhelm. A gaia ciência. São Paulo: Companhia das Letras, 2014.

. O nascimento da tragédia ou helenismo e pessimismo. São Paulo: Companhia das Letras, 2013.

NOLT, John. Informal logic: possible worlds and imagination. Blacklick: McGraw-Hill Companies, 1984.

NUSSBAUM, Martha Craven. The fragility of goodness: luck and ethics in Greek tragedy and philosophy. New York: Cambridge University Press, 2001.

PEREIRA, Caio Mário da Silva. Instituições de direito civil. Rio de Janeiro: Editora Forense, 2011. V. 5 .

PLATÃO. O Banquete. São Paulo: Abril Cultural, 1973. p. 7-59. (Coleção Os Pensadores).

PRADO, Camila Affonso. Responsabilidade civil dos pais pelo abandono afetivo dos filhos menores. 2012. 237 f. Dissertação (Mestrado em Direito Civil) - Faculdade de Direito, Universidade de São Paulo, São Paulo, 2012.

ROSENFIELD, Kathrin Holzermayr Lerrer. Estética. Rio de Janeiro: Jorge Zahar Editor, 2009. 
ROSENFIELD, Kathrin Holzermayr Lerrer. Édipo Rei: o direito na perspectiva da literatura. In: COSTA, Judith Martins (Org.). Édipo Rei. Narração e normatividade? Ensaios de direito e literatura. Rio de Janeiro: Editora GZ, 2012. p. 42-65.

. Édipo Rei: o direito na perspectiva da literatura. In: MARTINS-COSTA, Judith. (Coord.). Narração e normatividade. Ensaios de direito e literatura. Rio de Janeiro: GZ Editora, 2012. p. $42-65$.

SOUZA, Andreaze Bonifacio de. O princípio da afetividade no direito brasileiro: quando o abandono afetivo produz dano moral. Revista Ambito Jurídico, Rio Grande, ano XI, n. 53, maio 2008. Disponível em: <http://www.ambitojuridico.com.br/site/index.php?n_link=revista_artigos leitura\&artigo_id=2656>. Acesso em: 1 nov. 2013.

SOUZA, Osni de. Dano moral no direito de família. 2003. 273 f. Tese (Doutorado) - Faculdade de Direito, Universidade de São Paulo, São Paulo, 2003.

TARTUCE, Flávio. O princípio da afetividade no direito de família. Disponível em <http:// flaviotartuce.jusbrasil.com.br/artigos/121822540/o-principio-da-afetividade-no-direito-defamilia>. Acesso em: 30 out. 2013.

VIEIRA, Trajano. Antígone de Sófocles. São Paulo: Perspectiva, 2009. . Édipo em Colono de Sófocles. São Paulo: Perspectiva, 2005. . Édipo Rei de Sófocles. São Paulo: Perspectiva, 2011. 